\title{
First Record of Acetabularia myriospora (Polyphysaceae, Chlorophyta) in the Ceará State, Brazil
}

\begin{abstract}
On rocky shores, macroalgae play an ecological role as organizer of community structures, since they are source of food for many invertebrate species inhabiting their fronds, as well as providing shelter from predators, enhancing environment conditions and reducing water movement. With this in mind, detecting new species on a regional scale is of major importance for biodiversity monitoring and conservation. In the current study, a first record of the seaweed species Acetabularia myriospora was made in the offshore of Ceará state, Brazil. The frequency of occurrence of A. myriospora $(1.62 \%)$ is considered low whether compared to that of A. calyculus (17.43\%). This study is the first record of the species Acetabularia myriospora (Polyphysaceae, Chlorophyta) in the coastline of Ceará state.
\end{abstract}

Keywords: Macroalgae, Biodiversity, Coastline, Seaweed
Volume 6 Issue 5 - 2017

\author{
Naibe Cristina de Figueiredo,' Erivaldo \\ Laurindo Gomes,' Cl udio Giovanio da \\ Silva, ${ }^{2}$ Virg nia Maria CavalariHenriques ${ }^{3}$ \\ 'Laborat rio de Sanidade Aqu tica Centro de Ci ncias Agr rias \\ Universidade Federal Rural do Semi rido Brazil \\ ${ }^{2}$ P s gradua o em Produ o Animal Centro de Ci ncias Agr rias \\ Universidade Federal Rural do Semi rido Brazil \\ ${ }^{3}$ Departamento de Oceanografia e Limnologia Universidade \\ Federal do Rio Grande do Norte UFRN Brazil
}

Correspondence: Naibe Cristina de Figueiredo Laborat rio de Sanidade Aqu tica Centro de Ci ncias Agr rias Universidade Federal Rural do Semi rido Rio Grande do Norte Brazil,Tel 55 84986352976,Email naibecristina@hotmail.com

Received: November 14, 2017 | Published: December 04, 2017

\section{Introduction}

In the last century, an alarming rise in the dissemination of exotic species among oceans worldwide, boosted by expand of maritime commerce and fish farming. ${ }^{1}$ Studies on changes in standard species and habitat diversity are important to the understanding of natural species assemblage structures. ${ }^{2}$

Hard surfaces as intertidal areas or continuously submerged rocks are ideal habitats for releasing of several organisms, such as algae. ${ }^{3}$ On rocky shores, macroalgae play an ecological role as organizer of community structures, since they are source of food for many invertebrate species inhabiting their fronds, as well as providing shelter from predators, enhancing environment conditions and reducing water movement. ${ }^{4,5}$

With this in mind, detecting new species on a regional scale is of major importance for biodiversity monitoring and conservation. In the current study, the first record of the seaweed species Acetabularia myriospora was made in the offshore of Ceará state, northeast Brazil.

\section{Materials and methods}

The study was performed in the algae bank of Barrinha, located on the coastline of Icapuí city, in the state of Ceará, Brazil. A floristic survey was made in two manual random samplings during spring lowtide days. Species were found on rocks, sandstone reefs or even in tide pools. The material was collected and packaged into plastic bags, properly labeled, fixed in a solution as described by Reis TNDV, et al. ${ }^{6}$ formulated from formaldehyde in seawater at $4 \%$ and then taken to the laboratory, where zoobenthos were separated.

Identification was carried out following traditional techniques for seaweeds. ${ }^{7}$ Morphological and anatomical details were observed under stereoscopic microscope. Specimen frequency of occurrence was based on the number of samples, being estimated by the formula below:

$$
F o=\frac{T o \times 100}{T a}
$$

In which, Fo is the frequency of occurrence, To is the number of samples in which the taxon was found, and Ta is the total number of samples.Taxa classification as well as species and genus identifications were determined based on specific bibliography about flora and reviews of taxonomic groups. ${ }^{8}$

\section{Results and discussion}

The genus Acetabularia is divided into two subgenera: Acetabularia and Acicularia. ${ }^{9}$ In Brazil, fourspecies belonging to Acicularia were identified: Acetabularia schenckii Möbius, 1889; Acetabularia calyculus J.V.Lamourin Quoy \& Gaimard, 1824; Acetabularia crenulata J.V.Lamour, 1816 and Acetabularia myriospora Joly \& Cord.-Mar. in Jolyetal. 1965. ${ }^{10}$ Besides, two species belonging to Acicularia (Table 1) were observed in the study area.

Table I Taxonomic synopsis of the two seaweed species identified in Icapui coastline, Ceará state, Brazil

Taxon
Chlorophyta
Dasycladales
Polyphysaceae
Acetabularia calyculus*
Acetabularia myriospora**

*First occurrence in Icapuí costline

**First occurrence in Ceará state coastline 
The species A. Calyculus had already been recorded for the phycological flora of this state, ${ }^{11}$ however, it is the first register in Icapuí algae bank. In Brazil, A. Myriospora was firstly catalogued in the state of Bahia, after that, other records were made around the country. ${ }^{12}$ However, this species has not hitherto been identified in Ceará state coastline.

The frequency of occurrence of A. Myriospora $(1.62 \%)$ is considered low whether compared to that of A. calyculus $(17.43 \%)$ (Figure 1); this might be because A. myriospora is rarely sampled, mainly for being a small species inhabiting rocky shores and being associated to larger species.

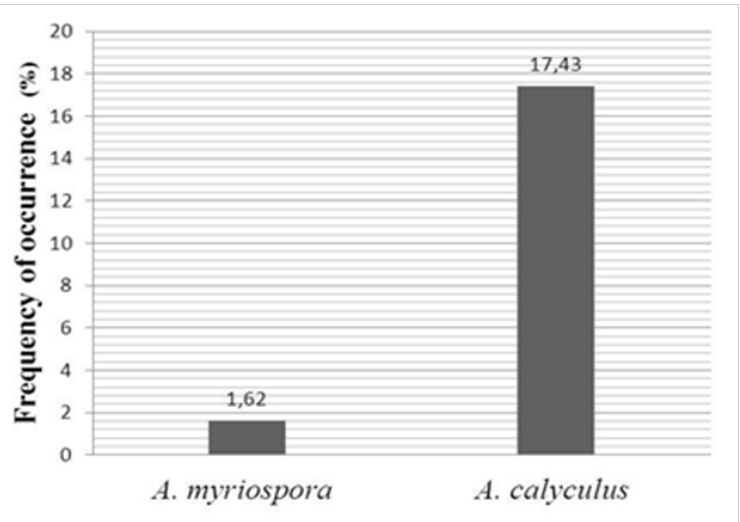

Figure I Frequency of occurrence of the two species of seaweeds (genus Acetabularia and subgenus Acicularia)sampled in the coastline of Icapuí, Ceará state, Brazil.

Hence, the importance of this study relies on the fact that little is known about the marine flora of the state, warning against the need for further studies to detect upcoming species. Indeed, two new species of algae were surveyed for the region of Icapuí; in addition, it has been the first record of the species Acetabularia myriospora(Polyphysaceae, Chlorophyta) in the coastline of Ceará state.

\section{Acknowledgements}

Thanks to Marcia Avelino Coelho for auditing the study. To Conselho Nacional de DesenvolvimentoCientífico e Tecnológico (CNPq) and Coordenação de Aperfeiçoamento de Pessoal de Nível Superior (CAPES) for financial support granted to post-graduation and graduation programs, and to the UFERSA for technical and scientific support.

\section{Conflicts of interest}

The authors declare no conflict of interests.

\section{References}

1. Marbà N, Arthur R, Alcoverro T. Getting turfed: The population and habitat impacts of Lophocladia lallemandii invasions on endemic Posidonia oceanica meadows. Aquatic Botany. 2014;116:76-82.

2. Raffo MP, Lo Russo V, Schwindt E. Introduced and native species on rocky shore macroalgal assemblages: Zonation patterns, composition and diversity. Aquatic Botany. 2013;112:57-65.

3. Arenas F, Bishop JD, Carlton JT, et al. Alien species and other notable records from a rapid assessment survey of marinas on the south coast of England. Journal of the Marine Biological Association of the UK. 2006;86(06):1329-1337.

4. Brito L, Széchy M, Cassano V. Levantamento Taxonômico das Macroalgas da Zona das Marés de Costões Rochosos Adjacentes ao Terminal Marítimo Almirante Maximiano Fonseca, Baía da Ilha Grande, RJ. Atlântica. 2002;24(1):17-26.

5. Jenkins SR, Hawkins SJ, Norton TA. Direct and indirect effects of a macroalgal canopy and limpet grazing in structuring a sheltered intertidal community. Marine Ecology Progress Series. 1999;188:81-92.

6. Reis TNDV, Guimarães-Barros NC, Vasconcelos ERTPP De, et al. Influence Of The Industrial Port Complex Of Suape (Western Tropical Atlantic) On The Biodiversity And Biomass Of Phaeophyceae. Tropical Oceanography. 2011;39(2):142-154.

7. Marins BV, Brasileiro PS, Barreto MBB, et al. Subtidal benthic marine algae of the Todos os Santos Bay, Bahia State, Brazil. Oecologia Brasiliensis. 200812(02):229-242.

8. Wynne MJ. The benthic marine algae of the tropical and subtropical Western Atlantic: changes in our understanding in the last half century. Algae. 2011;26(2):109-140.

9. Berger S, Fettweiss U, Gleissberg S, et al. 18S rDNA phylogeny and evaluation of cap development in Polyphysaceae (formerly Acetabulariaceae; Dasyladales, Chlorophyta). Phycologia. 2003;42(5):506-561.

10. Moura CWDN, Almeida WRD, Santos AAD, et al. Polyphysaceae (Dasycladales, Chlorophyta) in Todos os Santos Bay, Bahia, Brazil. Acta Botanica Brasilica. 2014;28(2):147-164.

11. Dantas NP, Alves MGL, Cunha VL da, et al. de. Reorganização Do Herbário Ficológico Do Instituto De Ciências Do Mar Da Universidade Federal Do Ceará. Arquivos de Ciências Do Mar. 1999;32:59-71.

12. Martins DV, Cordeiro-Manno M, Boccanera NB, et al. Clorofíceas marinhas bentônicas do município de salvador, bahia, brasil. 1991;18(2):115-133.

13. Nunes JM. de C. Catálogo De Algas Marinhas Bentônicas Do Estado Da Bahia, Brasil. Acta Botanica Malacitana. 1998;23:5-21. 